\title{
Enhanced viral production and virus-mediated mortality of bacterioplankton in a natural iron-fertilized bloom event above the Kerguelen Plateau
}

\author{
A. Malits ${ }^{1,2}$, U. Christaki ${ }^{3}$, I. Obernosterer ${ }^{4,5}$, and M. G. Weinbauer $^{1,2}$ \\ ${ }^{1}$ Sorbonne Universités, UPMC Univ Paris 06, UMR7093, LOV, Observatoire océanographique, 06230, \\ Villefranche/mer, France \\ ${ }^{2}$ CNRS, UMR7093, LOV, Observatoire océanographique, 06230, Villefranche/mer, France \\ ${ }^{3}$ INSU-CNRS, UMR8187 LOG, Laboratoire d'Océanologie et des Géosciences, Université du Littoral, \\ ULCO, 32 avenue Foch, 62930 Wimereux, France \\ ${ }^{4}$ Sorbonne Universités, UPMC Univ Paris 06, UMR7621, LOMIC, Observatoire océanographique, 66650 \\ Banyuls/mer, France \\ ${ }^{5}$ CNRS, UMR7621, LOMIC, Observatoire océanographique, 66650 Banyuls/mer, France
}

Correspondence to: A. Malits (amalits@cadic-conicet.gob.ar)

Received: 15 June 2014 - Published in Biogeosciences Discuss.: 15 July 2014

Revised: 14 October 2014 - Accepted: 15 October 2014 - Published: 8 December 2014

\begin{abstract}
Above the Kerguelen Plateau in the Southern Ocean natural iron fertilization sustains a large phytoplankton bloom over 3 months during austral summer. During the KEOPS1 project (KErguelen Ocean and Plateau compared Study1) we sampled this phytoplankton bloom during its declining phase along with the surrounding highnutrient-low-chlorophyll (HNLC) waters to study the effect of natural iron fertilization on the role of viruses in the microbial food web. Bacterial and viral abundances were 1.7 and 2.1 times, respectively, higher within the bloom than in HNLC waters. Viral production and virus-mediated mortality of bacterioplankton were 4.1 and 4.9 times, respectively, higher in the bloom, while the fraction of infected cells (FIC) and the fraction of lysogenic cells (FLC) showed no significant differences between environments. The present study suggests viruses to be more important for bacterial mortality within the bloom and dominate over grazing of heterotrophic nanoflagellates (HNFs) during the late bloom phase. As a consequence, at least at a late bloom stage, viral lysis shunts part of the photosynthetically fixed carbon in iron-fertilized regions into the dissolved organic matter (DOM) pool with potentially less particulate organic carbon transferred to larger members of the food web or exported.
\end{abstract}

\section{Introduction}

A quarter of a century ago the importance of viruses as the most abundant biological entity in the oceans (Bergh et al., 1989) and their role in the material and energy cycles were recognized (Proctor and Fuhrman, 1990; Suttle et al., 1990). Shortly afterwards, Smith et al. (1992) conducted the first study on viral distribution and their relationship to bacteria in the Southern Ocean. Since then, studies on viral abundance and production or infectivity in the cold, high-latitude marine environments remained limited or have only recently been accumulating (Bird et al., 1993; Brussaard et al., 2008b; Evans and Brussaard, 2012; Evans et al., 2009; Guixa-Boixereu et al., 2002; Higgins et al., 2009; Manganelli et al., 2009; Marchant et al., 2000; Payet and Suttle, 2008, 2013; Smith et al., 1992; Steward et al., 1996; Strzepek et al., 2005; Weinbauer et al., 2009). These observations demonstrate that viruses are ecologically as important in these cold environments as in the world's other oceans.

Viral lysis of cells converts particulate organic matter into dissolved and colloidal organic matter, reduces the carbon flow to higher trophic levels and increases the residence time of carbon and mineral nutrients in the euphotic zone (Fuhrman, 1999). By this process, called the "viral shunt" (Wilhelm and Suttle, 1999), heterotrophic bacteria are 
supplied with substrate, which finally increases respiration (Bonilla-Findji et al., 2008; Middelboe and Lyck, 2002). This could reduce the efficiency of the biological carbon pump, i.e. the process which transforms inorganic to organic carbon, part of which is then transferred to the deep ocean (Suttle, 2007). The relative significance of viral lysis and protistan grazing can strongly vary on temporal and spatial scales (Boras et al., 2009; Fuhrman and Noble, 1995). This has also been shown for cold marine environments (Boras et al., 2010; Guixa-Boixereu et al., 2002; Steward et al., 1996; Wells and Deming, 2006).

In about one-third of the World Ocean - including the subarctic northeast Pacific, the equatorial Pacific and the Southern Ocean, phytoplankton growth is limited by available iron, resulting in excess dissolved inorganic phosphorus and nitrogen (Martin and Fitzwater, 1988). In these highnutrient-low-chlorophyll (HNLC) regions, bacterioplankton are thought to be the key player of the "microbial ferrous wheel" (Kirchman, 1996), i.e. the uptake and remineralization of iron. Bacterioplankton contains more than twice the iron per carbon unit than eukaryotic phytoplankton, and they can thereby store up to $50 \%$ of the biogenic iron in the HNLC ocean (Tortell et al., 1996).

Viral activity has a potential impact on nutrient regeneration. Typically, nutrients released as a result of viral lysis are thought to be organically complexed, which may facilitate their use by marine plankton (Poorvin et al., 2004; Rue and Bruland, 1997). Iron released by viral lysis can account for more than $10 \%$ of ambient Fe concentrations (Gobler et al., 1997) and thus potentially relieve its limitation in depleted environments. Furthermore, marine viruses may serve as nuclei for iron adsorption and precipitation, and they thus represent a significant reservoir of iron in seawater (Daughney et al., 2004). Despite their key role, viruses are hardly included in iron enrichment studies. These experiments were originally stimulated by the "iron hypothesis" (Martin, 1990), which assigns iron a paramount role in controlling ocean productivity and consequently atmospheric carbon dioxide concentrations. Only 2 out of 13 iron fertilization experiments so far performed (Secretariat of the Convention on Biological Diversity, 2009) report on viral abundance and activity (Higgins et al., 2009; Weinbauer et al., 2009). Both studies - from the subarctic and Southern Ocean, respectively - found that viral production was significantly enhanced after iron fertilization.

Above the Kerguelen Plateau in the Southern Ocean, the largest HNLC ocean, a large phytoplankton bloom occurs annually during austral summer. The continuous supply of Fe and major nutrients from below has been shown to sustain this massive bloom (Blain et al., 2007). The region off Kerguelen provides the opportunity to study natural iron fertilization in the Southern Ocean and to compare it to blooms induced by mesoscale $\mathrm{Fe}$ additions. Within the KEOPS1 project (KErguelen Ocean and Plateau compared Study1, 2005-2007), we sampled the phytoplankton bloom above the

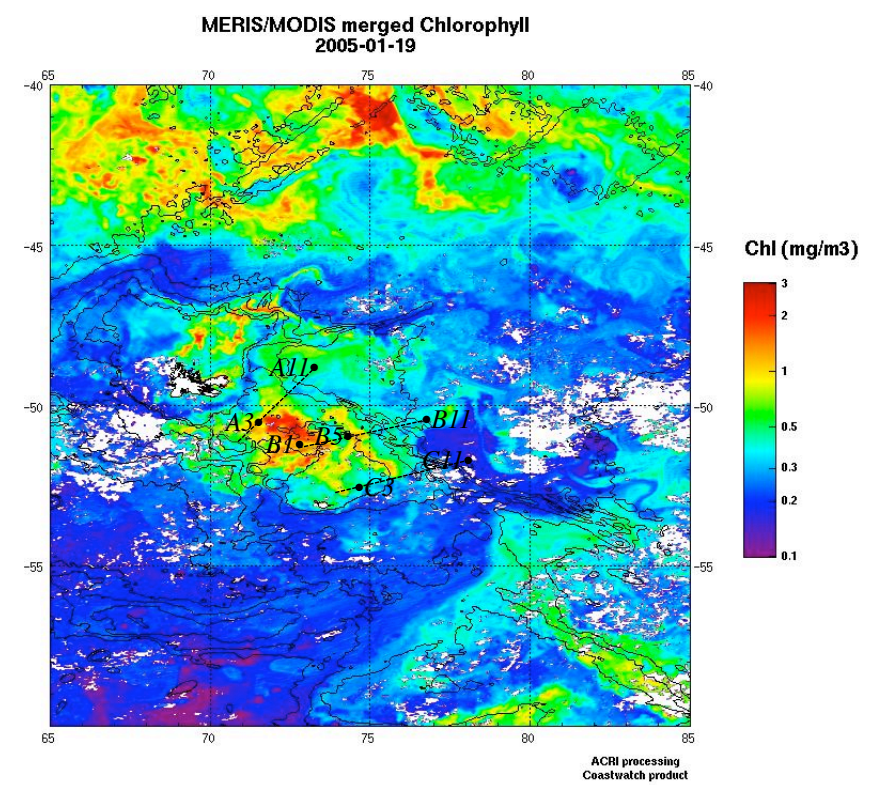

Figure 1. Real-time satellite images of chlorophyll during the KEOPS cruise dating from the first sampling of station A3 (19 Febuary 2005) (MODIS results provided by CSIRO marine research) and overlaid transects and sampled stations.

Kerguelen Plateau during its late successional stage $(\sim 3$ rd month) along with the surrounding HNLC waters. The aim of the present study was to assess the role of viruses within the microbial food web affected by natural Fe fertilization and to elucidate the possible implications for the final destiny of organic carbon. For this purpose, we measured viral production, the fraction of infected cells (FIC), lysogeny and estimated bacterial mortality through viral lysis in the bloom and surrounding HNLC waters.

\section{Material and methods}

\subsection{Description of the study site}

Sampling was performed in the Indian sector of the Southern Ocean above the Kerguelen Plateau (49-53 $\left.{ }^{\circ} \mathrm{S}, 72-78^{\circ} \mathrm{E}\right)$ in austral summer (18 January-13 February 2005) onboard the R/V Marion Dufresne in the framework of the project KEOPS (Blain et al., 2008). We sampled a large phytoplankton bloom dominated by diatoms from its peak to its decline (Mosseri et al., 2008) (Fig. 1). Satellite images dated the onset of this bloom more than 2 months before its first visit (Blain et al., 2007). Hydrographic conditions are described in detail in Park et al. (2008). Dissolved Fe concentrations in the surface mixed layer were low and similar on and off the plateau $(0.09 \pm 0.03 \mathrm{nM})$ but increased with depth above the plateau, reaching a mean maximum of $0.35 \mathrm{nM}$ at $500 \mathrm{~m}$. This strong vertical gradient in combination with physical features such as internal waves and tidal activity 
Table 1. Date, location, mixed layer depth $(\mathrm{Zm})$ and physicochemical characteristics of all sampled stations.

\begin{tabular}{|c|c|c|c|c|c|c|c|c|c|}
\hline Date & Station & Latitude & Longitude & $\begin{array}{r}\text { Water } \\
\text { type }\end{array}$ & $\mathrm{Zm} \mathrm{(m)}$ & $\begin{array}{l}\text { Sampling } \\
\text { depth (m) }\end{array}$ & $T{ }^{\circ} \mathrm{C}$ & Salinity & $\begin{array}{r}\text { Chl } a \\
\mu \mathrm{g} \mathrm{L}^{-1^{*}}\end{array}$ \\
\hline $1 / 19 / 05$ & A3-1 & $50^{\circ} 38^{\prime} \mathrm{S}$ & $72^{\circ} 05^{\prime} \mathrm{E}$ & $+\mathrm{Fe}$ & 52 & 10 & 3.5 & 33.9 & 0.94 \\
\hline $1 / 19 / 05$ & A3-1 & $50^{\circ} 38^{\prime} \mathrm{S}$ & $72^{\circ} 05^{\prime} \mathrm{E}$ & $+\mathrm{Fe}$ & 52 & 50 & 3.3 & 33.9 & 1.72 \\
\hline $1 / 19 / 05$ & A3-1 & $50^{\circ} 38^{\prime} \mathrm{S}$ & $72^{\circ} 05^{\prime} \mathrm{E}$ & $+\mathrm{Fe}$ & 52 & 100 & 3 & 33.9 & 1.38 \\
\hline $1 / 20 / 05$ & A11 & $49^{\circ} 09^{\prime} \mathrm{S}$ & $74^{\circ} 00^{\prime} \mathrm{E}$ & $+\mathrm{Fe}$ & 44 & 10 & 3.8 & 33.9 & 0.41 \\
\hline $1 / 20 / 05$ & A11 & $49^{\circ} 09^{\prime} \mathrm{S}$ & $74^{\circ} 00^{\prime} \mathrm{E}$ & $+\mathrm{Fe}$ & 44 & 75 & 3.3 & 33.9 & 0.52 \\
\hline $1 / 20 / 05$ & A11 & $49^{\circ} 09^{\prime} \mathrm{S}$ & $74^{\circ} 00^{\prime} \mathrm{E}$ & $+\mathrm{Fe}$ & 44 & 200 & 1.6 & 34.1 & 0.21 \\
\hline $1 / 26 / 05$ & C11-1 & $51^{\circ} 39^{\prime} \mathrm{S}$ & $78^{\circ} 00^{\prime} \mathrm{E}$ & $-\mathrm{Fe}$ & 73 & 10 & 1.9 & 33.8 & 0.19 \\
\hline $1 / 26 / 05$ & C11-1 & $51^{\circ} 39^{\prime} \mathrm{S}$ & $78^{\circ} 00^{\prime} \mathrm{E}$ & $-\mathrm{Fe}$ & 73 & 80 & 1.6 & 33.8 & 0.29 \\
\hline $1 / 26 / 05$ & C11-1 & $51^{\circ} 39^{\prime} \mathrm{S}$ & $78^{\circ} 00^{\prime} \mathrm{E}$ & $-\mathrm{Fe}$ & 73 & 200 & 1.3 & 34.2 & 0.01 \\
\hline $1 / 29 / 05$ & B11 & $50^{\circ} 30^{\prime} \mathrm{S}$ & $77^{\circ} 00^{\prime} \mathrm{E}$ & $-\mathrm{Fe}$ & 59 & 10 & 2.2 & 33.8 & 0.11 \\
\hline $1 / 29 / 05$ & B11 & $50^{\circ} 30^{\prime} \mathrm{S}$ & $77^{\circ} 00^{\prime} \mathrm{E}$ & $-\mathrm{Fe}$ & 59 & 120 & 0.5 & 33.8 & 0.24 \\
\hline $1 / 29 / 05$ & B11 & $50^{\circ} 30^{\prime} \mathrm{S}$ & $77^{\circ} 00^{\prime} \mathrm{E}$ & $-\mathrm{Fe}$ & 59 & 200 & 0.2 & 34.1 & 0.03 \\
\hline $2 / 1 / 05$ & B5 & $51^{\circ} 06^{\prime} \mathrm{S}$ & $74^{\circ} 36^{\prime} \mathrm{E}$ & $+\mathrm{Fe}$ & 84 & 60 & 2.8 & 33.9 & 1.54 \\
\hline $2 / 1 / 05$ & B5 & $51^{\circ} 06^{\prime} \mathrm{S}$ & $74^{\circ} 36^{\prime} \mathrm{E}$ & $+\mathrm{Fe}$ & 84 & 100 & 2.6 & 33.9 & 1.39 \\
\hline $2 / 2 / 05$ & B1 & $51^{\circ} 30^{\prime} \mathrm{S}$ & $73^{\circ} 00^{\prime} \mathrm{E}$ & $+\mathrm{Fe}$ & 59 & 60 & 3.3 & 33.9 & 1.29 \\
\hline $2 / 2 / 05$ & B1 & $51^{\circ} 30^{\prime} \mathrm{S}$ & $73^{\circ} 00^{\prime} \mathrm{E}$ & $+\mathrm{Fe}$ & 59 & 100 & 2.7 & 33.9 & 1.04 \\
\hline $2 / 4 / 05$ & A3-4 & $50^{\circ} 39^{\prime} \mathrm{S}$ & $72^{\circ} 05^{\prime} \mathrm{E}$ & $+\mathrm{Fe}$ & 80 & 50 & 3.6 & 33.9 & 1.48 \\
\hline $2 / 4 / 05$ & A3-4 & $50^{\circ} 39^{\prime} \mathrm{S}$ & $72^{\circ} 05^{\prime} \mathrm{E}$ & $+\mathrm{Fe}$ & 80 & 150 & 1.7 & 33.9 & 1.54 \\
\hline $2 / 6 / 05$ & C11-2 & $51^{\circ} 39^{\prime} \mathrm{S}$ & $78^{\circ} 00^{\prime} \mathrm{E}$ & $-\mathrm{Fe}$ & 20 & 60 & 1.6 & 33.8 & 0.26 \\
\hline 2/6/05 & C11-2 & $51^{\circ} 39^{\prime} \mathrm{S}$ & $78^{\circ} 00^{\prime} \mathrm{E}$ & $-\mathrm{Fe}$ & 20 & 100 & 0.6 & 33.9 & 0.20 \\
\hline 2/9/05 & $\mathrm{C} 3$ & $52^{\circ} 43^{\prime} \mathrm{S}$ & $74^{\circ} 49^{\prime} \mathrm{E}$ & $-\mathrm{Fe}$ & 42 & 60 & 2.5 & 33.9 & 0.19 \\
\hline $2 / 9 / 05$ & $\mathrm{C} 3$ & $52^{\circ} 43^{\prime} \mathrm{S}$ & $74^{\circ} 49^{\prime} \mathrm{E}$ & $-\mathrm{Fe}$ & 42 & 100 & 1.9 & 33.9 & 0.17 \\
\hline
\end{tabular}

$T$ : temperature in ${ }^{\circ}$ Celsius; $\mathrm{Chl} a$ : total chlorophyll $a,+\mathrm{Fe}$ : iron-fertilized, $-\mathrm{Fe}$ : HNLC waters; * Data are from Uitz et al. (2009)

sustained the phytoplankton bloom above the plateau (Blain et al., 2007).

\subsection{Sampling strategy}

Water was collected using General Oceanics 12 L Niskin bottles mounted on a rosette with a Sea Bird SBE19 plus CTD sensor for salinity, temperature and oxygen from two to three depths (within and below the surface mixed layer) at the following stations to cover the centre and borders of each of three transects (A, B, C): A3, A11, B1, B5, B11, C3 and $\mathrm{C} 11$ (Fig. 1, Table 1). The stations $\mathrm{A} 3$ and $\mathrm{C} 11$ were considered as the most contrasting stations and sampled repeatedly. The first sampling of station A3 (A3-1) was done during the peak of the bloom, and about 2 weeks later station A3 was re-sampled at a fourth visit (A3-4) during the decline of the bloom. Station B5 was situated within a new phytoplankton bloom above the Kerguelen Plateau (Obernosterer et al., 2008). Station A11 was located in iron-fertilized waters. The annually occurring spring bloom developed prior to our visit, explaining the low concentrations of $\mathrm{Chl} a$ at this site (Table 1). Station C11 was in HNLC waters off the Kerguelen Plateau and was sampled twice (Table 1). Stations B11 and C3 were in different environments with relatively low $\mathrm{Chl} a$ contents and will also be considered as representative of HNLC conditions in this study.
Total chlorophyll $a$ (Chl $a$ and divinyl-Chl $a$ ) was measured by high-performance liquid chromatography (HPLC, Van Heukelem and Thomas, 2001; Uitz et al., 2009).

\subsection{Enumeration of viruses and prokaryotes}

Subsamples $(2 \mathrm{~mL})$ were fixed with glutaraldehyde $(0.5 \%$ final concentration), incubated for $15-30 \mathrm{~min}$ at $4{ }^{\circ} \mathrm{C}$, subsequently frozen in liquid nitrogen and stored at $-80^{\circ} \mathrm{C}$. Within a few days samples were thawed and viral particles and bacteria were stained with SYBR Green I (molecular probes) and quantified using a FACScalibur (Becton and Dickinson) flow cytometer after dilution with TE buffer $(10 \mathrm{mM}$ Tris, $1 \mathrm{mM}$ EDTA, ph $=8)$. For viruses an optimized protocol by Brussaard (2004) was followed. Viruses and prokaryotes were determined in plots of $90^{\circ}$ light scatter (SSC) and green DNA fluorescence. Differences in the green fluorescence and side scatter signature in the cytometric plot allowed to separate prokaryotes with low nucleic acid content (LNA) from prokaryotes with high nucleic acid content (HNA) as previously described by Gasol et al. (1999). Similarly, different size classes of viruses were distinguished on the basis of green fluorescence. Abundances were calculated by using the flow rate measurements. Flow-cytometric assessment of viral abundance may encompass particles other than viruses such as bacterial vesicles (Biller et al., 2014). However, since bacterial and viral parameters were related 
significantly (Table 4), a potential overestimation of viral abundances probably did not bias the conclusions of the study.

To convert bacterial abundance (BA) to biomass, we used a conversion factor of $12.4 \mathrm{fg} \mathrm{C} \mathrm{Cell}^{-1}$ for oceanic prokaryotes (Fukuda et al., 1998).

\subsection{Bacterial production}

The incorporation of ${ }^{3} \mathrm{H}$ leucine into protein (Smith and Azam, 1992) was used to estimate the production of heterotrophic bacteria (BP). At each depth, $1.5 \mathrm{~mL}$ duplicate samples and a trichloroacetic acid (TCA)-killed control were incubated with a mixture of $\mathrm{L}-[4,5-3 \mathrm{H}]$ leucine (Amersham, $160 \mathrm{Cimmol}^{-1}$ ) and nonradioactive leucine added at final concentrations of 7 and $13 \mathrm{nM}$ for the upper $100 \mathrm{~m}$, and 13 and $7 \mathrm{nM}$ for the $100-200 \mathrm{~m}$ depth layer. Samples were incubated in the dark at the ambient temperature of the depth where samples were collected. The incubation time (2$3 \mathrm{~h}$ ) was tested to satisfy linear incorporation with time. We checked by concentration kinetics $(2.5,5,10,20$ and $40 \mathrm{nM})$ at three stations inside and outside the bloom at 5 and $175 \mathrm{~m}$ depths that there was no isotopic dilution. The theoretical conversion factor of $1.55 \mathrm{~kg}$ of $\mathrm{C} \mathrm{mol}^{-1}$ was used to convert leucine incorporation rates to prokaryotic carbon production (Kirchman, 1993).

\subsection{Viral production, the fraction of infected cells and the fraction of lysogenic cells}

Lytic viral production $\left(\mathrm{VP}_{1}\right)$, the $\mathrm{FIC}$, induced viral production $\left(\mathrm{VP}_{\mathrm{i}}\right)$ and the fraction of lysogenic cells (FLC) were estimated using the virus reduction approach (VRA; Weinbauer et al., 2010; Wilhelm et al., 2002). The rationale behind VRA is to reduce viral abundance in order to stop new viral infection. Thus, the viruses produced originate from already-infected cells. Briefly, bacteria from $200 \mathrm{~mL}$ raw seawater were concentrated using a tangential flow system with a peristaltic pump (Watson-Marlow 323) equipped with a $0.2 \mu \mathrm{m}$ cartridge (VIVAFLOW 50). To obtain virus-free seawater, the $0.2 \mu \mathrm{m}$ pore-size ultrafiltrate was passed through a 100kDalton cartridge (VIVAFLOW 50). The bacterial concentrates were brought up to the original volume with virusfree seawater and incubated in duplicate $50 \mathrm{~mL}$ Falcon tubes in the dark at $\pm 2{ }^{\circ} \mathrm{C}$ in situ temperature for $24 \mathrm{~h}$. Lysogeny was estimated by adding mitomycin C (SigmaChemical Co., Cat. No. M0503, final concentration $1 \mu \mathrm{g} \mathrm{mL}^{-1}$ ) to duplicate $50 \mathrm{~mL}$ Falcon tubes in order to induce the lytic cycle in lysogens; untreated duplicate samples served as controls (Paul and Weinbauer, 2010). Subsamples ( $2 \mathrm{~mL}$ ) for viral and bacterial abundance from each incubation were taken immediately ( $t_{0}$ samples) and every $3-4 \mathrm{~h}$, fixed with glutaraldehyde ( $0.5 \%$ final concentration), incubated for 15-30 minutes at $4{ }^{\circ} \mathrm{C}$, subsequently frozen in liquid nitrogen and stored at $-80^{\circ} \mathrm{C}$ until enumeration using a flow cytometer as described above. $\mathrm{VP}_{1}$ was calculated as

$\mathrm{VP}_{1}=\left(V_{2}-V_{1}\right) /\left(t_{2}-t_{1}\right)$

where $V_{1}$ and $V_{2}$ are viral abundances and $t_{1}$ and $t_{2}$ the elapsed time. Dividing the number of produced phages by an estimated burst size (BS, i.e. the number of phages released during the lysis of a single host) yields the number of lysed cells and thus gives an estimation of FIC (Weinbauer et al., 2002). FIC was calculated as

$\mathrm{FIC}=100 \cdot\left[V_{2}-V_{1}\right] / \mathrm{BS} / \mathrm{BA}$,

where $\mathrm{BA}$ is the bacterial abundance at $t_{0}$. The difference in phage production between the lysogeny treatment and the control is $\mathrm{VP}_{i}$, calculated as

$\mathrm{VP}_{\mathrm{i}}=\left(V_{\mathrm{MC}}-V_{\mathrm{C}}\right) /\left(t_{2}-t_{1}\right)$,

where $V_{\mathrm{MC}}$ and $V_{\mathrm{C}}$ are the maximum difference in viral abundance at corresponding time points in control and mitomycin $\mathrm{C}$ treatments, respectively. Dividing the number of induced phages by $\mathrm{BS}$ and the bacterial abundance at $t_{0}(\mathrm{BA})$ gives an estimate of the FLC:

$\mathrm{FLC}=100 \cdot\left(\left[V_{\mathrm{MC}}-V_{\mathrm{C}}\right] / \mathrm{BS} / \mathrm{BA}\right)$.

Calculations were performed for each replicate separately.

\subsection{Contact rates}

The rates of contact $\left(R\right.$, number $\left.\mathrm{mL}^{-1} \mathrm{~d}^{-1}\right)$ between viruses and bacteria were calculated by using the following equations (Murray and Jackson, 1992).

$R=S h \cdot 2 \pi d \cdot D_{\mathrm{v}} \cdot \mathrm{VA} \cdot \mathrm{BA}$,

where $S h$ is the Sherwood number (1.06 for a bacterial community with $10 \%$ motile cells; Wilhelm et al., 1998), $d$ is the diameter of the target; VA and BA are the abundances of viruses and bacteria, respectively; and $D_{\mathrm{v}}$ is the diffusivity of viruses.

$D_{\mathrm{v}}=k \cdot T /\left(3 \cdot \pi \cdot \mu \cdot d_{\mathrm{v}}\right)=5 \cdot 10^{-8} \mathrm{~cm}^{2} \mathrm{~s}^{-1}$,

where $k$ is the Boltzmann constant $\left(1.38 \times 10^{-23} \mathrm{~J} \mathrm{~K}^{-1}\right), T$ is the in situ temperature $(\sim 275 \mathrm{~K}), \mu$ is the viscosity of water (Pascal s${ }^{-1}$ ) and $d_{\mathrm{v}}$ is the diameter of the viral capsid $(\sim 60 \mathrm{~nm})$. The contact rates were divided by in situ bacterial abundance to estimate the number of contacts per cell on a daily basis.

\subsection{Bacterial mortality}

To obtain the rate of cell lysis, viral production corrected for in situ bacterial abundance was divided by an estimated BS following the approach of Wells and Deming (2006), i.e. dividing the number of viruses produced during the first hours 
Table 2. Average \pm SD values of viral and bacterial parameters from the iron-fertilized and HNLC stations in the upper $200 \mathrm{~m}$ water layer and results from one-way ANOVA for normally distributed data and Kruskal-Wallis test for nonparametric data. Ranges are given in parentheses. The average ratio between the two environments is shown, and significant differences are indicated.

\begin{tabular}{|c|c|c|c|}
\hline Parameters & Fe-fertilized stations & HNLC stations & Ratio \\
\hline $\mathrm{BA} \mathrm{mL}^{-1}$ & $3.9 \pm 0.9(1.9-5.3) \times 10^{5}$ & $2.4 \pm 0.7(1.3-3.8) \times 10^{5}$ & $1.7^{* * *}$ \\
\hline $\mathrm{BP} \mu \mathrm{gCL} \mathrm{L}^{-1} \mathrm{~d}^{-1}$ & $1.1 \pm 0.7(0.1-2.5)$ & $0.3 \pm 0.2(0.1-0.7)$ & 4.1 ${ }^{* * *}$ \\
\hline $\mathrm{VA} \mathrm{mL}^{-1}$ & $9.9 \pm 3.6(3.4-14.2) \times 10^{6}$ & $4.7 \pm 1.4(3.1-7.4) \times 10^{6}$ & 2.1 * \\
\hline $\mathrm{VP}_{1} \mathrm{~mL}^{-1} \mathrm{~d}^{-1}$ & $59.0 \pm 47.1(9.9-117.9) \times 10^{6}$ & $14.5 \pm 7.4(6.0-25.6) \times 10^{6}$ & 4.1* \\
\hline$V P_{i} \mathrm{~mL}^{-1} \mathrm{~d}^{-1^{\mathrm{a}}}$ & $50.9 \pm 46.4(2.8-125.5) \times 10^{6}$ & $13.9 \times 10^{6}$ & 3.7 \\
\hline FIC $\%$ & $22 \pm 17(4-47)$ & $12 \pm 7(3-23)$ & 1.8 \\
\hline FLC $\%$ b & $10 \pm 14(1-31)$ & $3 \pm 2(1-4)$ & 4.0 \\
\hline $\begin{array}{l}\text { Prophage replication rate } \\
\text { rate } \mathrm{mL}^{-1} \mathrm{~d}^{-1^{b}}\end{array}$ & $18.1 \pm 29.2(0.6-61.5) \times 10^{3}$ & $1.0 \pm 1.2(0.2-2.4) \times 10^{3}$ & 18.5 \\
\hline$R$ cell $^{-1} \mathrm{~d}^{-1}$ & $29.4 \pm 11.1(10.3-43.0)$ & $14.2 \pm 4.4(9.3-22.4)$ & $2.1^{*}$ \\
\hline lysed bacteria $\mathrm{mL}^{-1} \mathrm{~d}^{-1}$ & $5.4 \pm 4.1(0.8-10.3) \times 10^{5}$ & $1.1 \pm 0.6(0.4-2.1) \times 10^{5}$ & $4.9^{*}$ \\
\hline VMM \% & $72 \pm 72(8-202)$ & $27 \pm 19(6-58)$ & 2.6 \\
\hline
\end{tabular}

VA: viral abundance; $\mathrm{VP}_{1}$ : lytic viral production; $\mathrm{VP}_{\mathrm{i}}$ : induced viral production; FIC: fraction of infected cells; FLC: fraction of lysogenic cells; BA: bacterial abundance; BP: bacterial production; $R$ : viral contacts per cell and day; VMM: virus-mediated bacterial mortality.

* $P<0.05,{ }^{* *} P<0.001, * * * \quad P<0.0001$

a Detected in 6 out of 15 essays, only 1 in HNLC waters. ${ }^{b}$ Detected in 7 out of 15 essays.

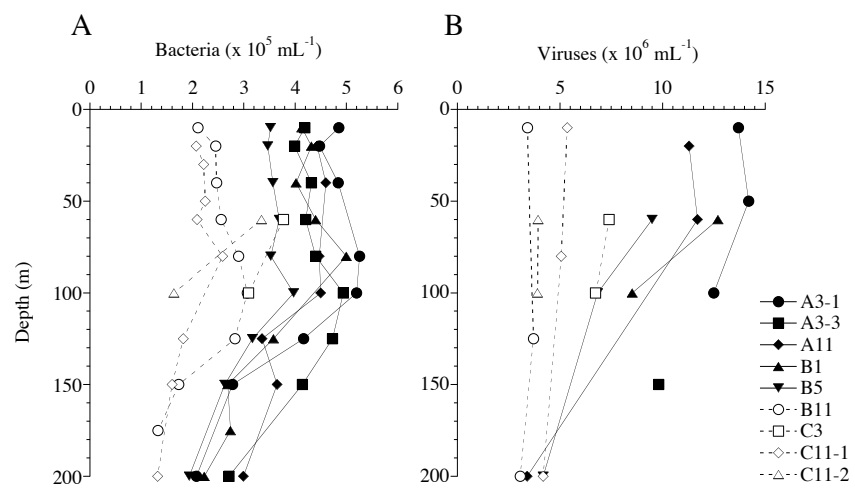

Figure 2. Depth profiles of bacterial (a) and viral abundance (b) in the Kerguelen study area. Full symbols indicate Fe-fertilized sites; open symbols indicate HNLC waters.

of incubation by the concomitant decline of bacterial abundance. The number of lysed bacteria was converted into carbon by the factor of $12.4 \mathrm{fg} \mathrm{C} \mathrm{Cell}^{-1}$ (Fukuda et al., 1998). The fraction of bacterial mortality through viral lysis (VMM) was calculated following the model by Binder (1999).

$\mathrm{VMM}=\mathrm{FIC} / \mathrm{LN}(2) \cdot(1-0.186-\mathrm{FIC})$

\subsection{Statistics}

Normal distribution of data was checked using the ShapiroWilk $W$ test. Differences between different trophic situations were analysed by the Kruskal-Wallis test for nonparametric data and by one-way ANOVA (analysis of variance) for normally distributed data. Spearman rank correlation for non- normally distributed data was applied. Significance was considered for $P<0.05$.

\section{Results}

\subsection{Bacterial and viral abundances}

From surface water down to $200 \mathrm{~m}$, BA was on average 1.7 fold higher within the Fe-fertilized $\left(3.9 \times 10^{5} \mathrm{~mL}^{-1}\right)$ than in HNLC waters $\left(2.4 \times 10^{5} \mathrm{~mL}^{-1}\right.$, Kruskal-Wallis test, $P<0.0001$, Table 2; Fig. 2). Similarly, viral abundance (VA) averaged $9.9 \times 10^{6} \mathrm{~mL}^{-1}$ at the Fe-fertilized stations and was twice as high as in the HNLC environments $\left(4.7 \times 10^{6}\right.$ particles $\mathrm{mL}^{-1}$, Kruskal-Wallis test, $P<0.05$, Table 2). VA ranged from 3.1 to $14.2 \times 10^{6} \mathrm{~mL}^{-1}$, with the highest values found at the main bloom station $\mathrm{A} 3$ and the lowest value detected in the deep layer of the HNLC station B11. Viruses were homogeneously distributed with depth at the HNLC stations. The virus-to-bacteria ratio (VBR) ranged from 11 to 34 and averaged 21 without significant differences between stations or trophic situations.

\subsection{Contact rates}

Contact rates were significantly higher at the Fe-fertilized stations than in HNLC waters (Kruskal-Wallis test, $P<0.05$, Table 2). At the Fe-fertilized stations, on average $29.4 \pm 11.1$ viruses contacted a bacterial cell per day, while in the HNLC waters contact rates were $14.2 \pm 4.4$ viruses cell ${ }^{-1} \mathrm{~d}^{-1}$, with the highest values at the bloom station $\mathrm{A} 3$ and the lowest at the HNLC station B11 in accordance to the highest and lowest viral abundances, respectively (see Fig. 2). 
Table 3. In situ BP and viral parameters from all virus reduction experiments.

\begin{tabular}{|c|c|c|c|c|c|c|c|}
\hline Station & Water type & Depth (m) & $\mu \mathrm{gCL}^{-1} \mathrm{~d}^{-1}$ & $\begin{array}{r}\mathrm{VP}_{1} \\
10^{6} \mathrm{~mL}^{-1} \mathrm{~d}^{-1}\end{array}$ & FIC \% & FLC \% & VMM \% \\
\hline A3-1 & $+\mathrm{Fe}$ & 10 & 2.5 & 16.7 & 12 & 31 & 25 \\
\hline A3-1 & $+\mathrm{Fe}$ & 50 & 1.9 & 15.6 & 6 & 6 & 12 \\
\hline A3-1 & $+\mathrm{Fe}$ & 100 & 2.4 & 56.4 & 10 & ND & 19 \\
\hline A3-4 & $+\mathrm{Fe}$ & 50 & 1.2 & 105.6 & 34 & ND & 106 \\
\hline A3-4 & $+\mathrm{Fe}$ & 150 & 0.3 & 82.4 & 36 & ND & 115 \\
\hline B1 & $+\mathrm{Fe}$ & 60 & 1.7 & 117.9 & 41 & ND & 147 \\
\hline B1 & $+\mathrm{Fe}$ & 100 & 0.2 & 115.6 & 47 & 3 & 202 \\
\hline B5 & $+\mathrm{Fe}$ & 100 & 1.1 & 11.2 & 4 & 1 & 8 \\
\hline A11 & $+\mathrm{Fe}$ & 200 & 0.3 & 9.9 & 7 & ND & 14 \\
\hline B11 & $-\mathrm{Fe}$ & 10 & 0.2 & 16.3 & 14 & ND & 29 \\
\hline B11 & $-\mathrm{Fe}$ & 120 & 0.3 & 25.6 & 23 & 1 & 58 \\
\hline B11 & $-\mathrm{Fe}$ & 200 & 0.1 & 6.0 & 11 & 3 & 24 \\
\hline $\mathrm{C} 3$ & $-\mathrm{Fe}$ & 60 & 0.2 & 20.1 & 6 & no exp & 11 \\
\hline C3 & $-\mathrm{Fe}$ & 100 & 0.4 & 16.7 & 22 & no exp & 55 \\
\hline C11-1 & $-\mathrm{Fe}$ & 10 & 0.4 & 11.2 & 8 & ND & 17 \\
\hline C11-1 & $-\mathrm{Fe}$ & 80 & 0.7 & 9.6 & 9 & 4 & 17 \\
\hline C11-1 & $-\mathrm{Fe}$ & 200 & 0.1 & 7.5 & 6 & ND & 12 \\
\hline $\mathrm{C} 11-2$ & $-\mathrm{Fe}$ & 60 & 0.3 & 25.1 & 20 & no exp & 47 \\
\hline C11-2 & $-\mathrm{Fe}$ & 100 & 0.2 & 6.4 & 3 & no exp & 6 \\
\hline
\end{tabular}

$\mathrm{VP}_{1}$ : lytic viral production; FIC: fraction of infected cells; FLC: fraction of lysogenic cells; VMM: virus-mediated bacterial mortality; ND: not detectable; no exp: no lysogen induction essay.

A
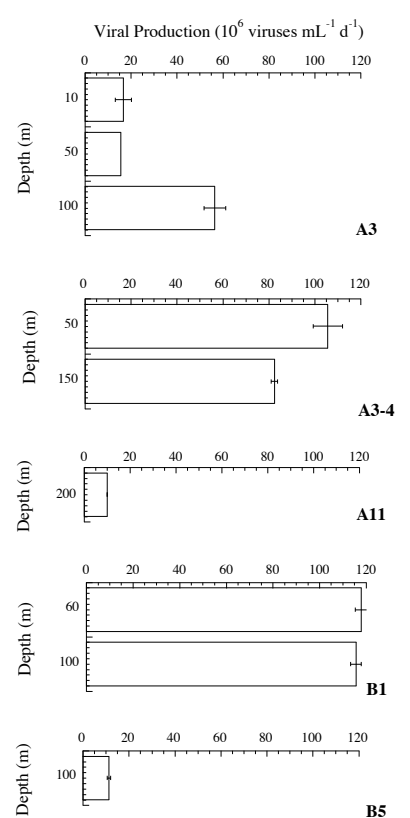

\section{B}
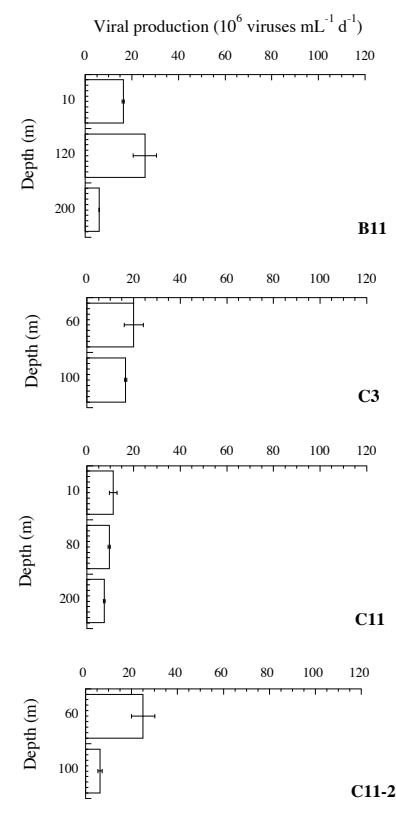

Figure 3. Lytic viral production from the Fe-fertilized (a) and HNLC (b) stations. Values are the averages of duplicates, and error bars indicate the minimum and maximum values. When not visible, error bars are within the width of the line.

\subsection{Bacterial production, viral production, fraction of infected cells and lysogeny}

Bacterial production ranged from 0.1 to $0.7 \mu g \mathrm{CL}^{-1} \mathrm{~d}^{-1}$ at the HNLC stations and from 0.1 to $2.5 \mu \mathrm{gC} \mathrm{L}^{-1} \mathrm{~d}^{-1}$ at the $\mathrm{Fe}$ fertilized stations (Table 2). The highest values were found throughout the depth profile of the main bloom station A3-1 and the lowest values were measured between 150 and $200 \mathrm{~m}$ at the HNLC stations. Despite the wide range of values, BP was on average 4 times higher at the Fe-fertilized stations than at the HNLC stations (Kruskal-Wallis test, $P<0.0001$, Table 2).

Initial virus abundance in the VRA was $45 \pm 25 \%$ (11$88 \%$ ) of in situ abundance. The recovery efficiency for bacteria in the VRA was on average $26 \pm 18 \%(5-83 \%)$.

Lytic viral production corrected for in situ bacterial abundance averaged $59.0 \times 10^{6} \mathrm{~mL}^{-1} \mathrm{~d}^{-1}$ in the naturally $\mathrm{Fe}$ fertilized patch, compared to $14.5 \times 10^{6} \mathrm{~mL}^{-1} \mathrm{~d}^{-1}$ in the HNCL environments. This 4.1-fold difference was significant (Kruskal-Wallis test, $P<0.05$, Table 2). Induced viral production $\left(\mathrm{VP}_{\mathrm{i}}\right)$ was detected in four out of nine stations (three fertilized stations and one HNLC station, Table 3) and averaged $44.8 \pm 44.2 \times 10^{6} \mathrm{~mL}^{-1} \mathrm{~d}^{-1}$ (Table 2). $\mathrm{VP}_{1}$ at the main bloom station $\mathrm{A} 3$ at $50 \mathrm{~m}$ increased from the first visit $\left(15.6 \times 10^{6} \mathrm{~mL}^{-1} \mathrm{~d}^{-1}\right)$ to the fourth visit $\left(105.6 \times 10^{6} \mathrm{~mL}^{-1} \mathrm{~d}^{-1}\right)$ by a factor of 6.8 , when the decline of the bloom was sampled. BS estimates ranged from 36 to 261 viruses per bacterial cell, with mean values 
Table 4. Nonparametric Spearman rank correlation matrix for chlorophyll $a$, bacterial and viral parameters from the fertilized ( $n=8-9$, except for BP-BA-Chl $a: 36-41)$ and HNLC stations ( $n=10$, except for BP-BA-Chl $a: 23-31)$. Bold numbers are significant $r$ values ( $P<0.05$, ${ }^{* *} P<0.001$, $\left.{ }^{* * *} P<0.0001\right)$.

\begin{tabular}{lrrrrr}
\hline & Chl $a$ & BA & BP & VA & VP $_{1}$ \\
\hline Fe-fertilized & & & & & \\
BA & 0.209 & & & & \\
BP & 0.243 & $\mathbf{0 . 6 3 3}^{* * *}$ & & & \\
VA & 0.357 & 0.548 & $\mathbf{0 . 7 6 2}^{*}$ & & \\
VP & 0.083 & 0.476 & -0.050 & 0.310 & \\
FIC & -0.183 & 0.333 & -0.267 & 0.095 & $\mathbf{0 . 9 0 0}^{* *}$ \\
\hline HNLC & & & & & \\
BA & $\mathbf{0 . 6 8 8}^{*}$ & & & & \\
BP & $\mathbf{0 . 3 8 0}^{*}$ & $\mathbf{0 . 6 3 5}^{*}$ & & & \\
VA & 0.164 & 0.576 & 0.515 & & \\
VP & 0.426 & $\mathbf{0 . 7 4 6}^{*}$ & 0.406 & 0.273 & \\
FIC & 0.168 & 0.304 & 0.310 & -0.249 & 0.608 \\
\hline
\end{tabular}

BA: bacterial abundance; BP: bacterial production; VA: viral abundance; $\mathrm{VP}_{1}$ : lytic viral production; FIC: fraction of infected cells.

of $115 \pm 74$ viruses per bacterial cell in the bloom and $139 \pm 77$ viruses per bacterial cell in the HNLC waters.

Although FIC values at the Fe-fertilized stations almost doubled those in HNLC waters, this difference between environments was not significant (Kruskal-Wallis test, Table 2). Average values for duplicate assays ranged from 4 to $47 \%$ (average: $22 \%$ ) in fertilized waters and from 3 to $23 \%$ (average: $12 \%$ ) in HNLC waters. Lysogenic infection of bacterioplankton could be detected only in 7 out of 15 lysogenic phage induction essays and ranged from 1 to $31 \%$ in fertilized waters and from 1 to $4 \%$ in the HNLC environment.

At the fertilized stations, on average $5.4 \pm 4.1 \times 10^{5}$ bacteria $\mathrm{mL}^{-1} \mathrm{~d}^{-1}$ were lysed, 5 times more than at the HNLC stations $\left(1.1 \pm 0.610^{5}\right.$ bacteria $\mathrm{mL}^{-1} \mathrm{~d}^{-1}, P<0.05$, KruskalWallis test, Table 2). The resulting virus-mediated loss of bacterial standing stock was on average $44 \pm 24 \%$ per day in the HNLC waters and more than twice as high at the fertilized stations, although this was not significant $\left(104 \pm 76 \% \mathrm{~d}^{-1}\right.$, Kruskal-Wallis test, Table 2). The fraction of bacterial mortality through viral lysis (VMM) following the model by Binder (1999) averaged $72 \pm 72 \%$ in the bloom and $27 \pm 19 \%$ at the HNLC sites (Kruskal-Wallis, ns, Table 2).

\subsection{Relation between the different parameters}

Spearman rank correlation coefficients $\rho$ for chlorophyll $a$, viral and bacterial parameters from HNLC and bloom stations are shown in Table 4. BA and BP correlated positively throughout trophic situations, but only in HNLC waters did $\mathrm{BA}$ and BP increase with $\mathrm{Chl} a$. In the fertilized waters VA correlated positively with BP, while in HNLC waters VP increased with BA. Only in these waters did $\mathrm{VP}_{1}$ correlate sig- nificantly and positively with the fraction of infected cells (Table 4).

\section{Discussion}

Viruses were the dominant mortality factor of bacteria during the late stage of a phytoplankton bloom induced by natural iron fertilization in the Southern Ocean (second visit to A3) but accounted for a small part of bacterial mortality within a new bloom (station B5, Table 3). Additionally, observations from the early bloom phase showed that heterotrophic nanoflagellates (HNFs) dominated the loss of BP, and viruses accounted for only $10 \%$ of bacterial mortality (Christaki et al., 2014). These seasonal dynamics point to a switch from an efficient functioning of the microbial food web during the onset of the phytoplankton bloom to a microbial food web where organic carbon is mainly processed by the viral shunt. The increase in virus-mediated release of dissolved organic carbon over time has important consequences for the fate of part of the photosynthetically fixed carbon and reduces its transfer to higher trophic levels and export.

\subsection{Comparison of viral data within high-latitude marine environments}

Viral production rates in the present study match well the data obtained from the Australian sector of the Southern Ocean (Evans et al., 2009) and are within the range of VP rates from an iron-induced bloom in the subarctic Pacific (Higgins et al., 2009). However, our VP rates are high when compared to data from an artificial iron-fertilization experiment in the Southern Ocean (Weinbauer et al., 2009) or those from other high-latitude marine environments, i.e. the Arctic Sea (Steward et al., 1996; Boras et al., 2010) (Table 5). Differences between studies could be due to spatiotemporal variations of VP; however, it is also conceivable that differences between methods (Helton et al., 2005; Weinbauer et al., 2009; Winget et al., 2005) have contributed to the variability of reported VP data.

In the present study, the burst size averaged 128 viruses per bacterial cell throughout the experiments. This value is high compared to two studies from the Southern Ocean where measured BS was about 40 viruses per bacterial cell (Strzepek et al., 2005; Weinbauer et al., 2009) and to a study in early spring above and off the Kerguelen Plateau where BS evaluated with TEM observations varied from 6 to 88 viruses per bacterial cell (mean $\pm S D, 22 \pm 15$; Christaki et al., 2014). These different BS could be inherent to the study regions or due to the used method, i.e. estimating BS by an increase in VA and a decrease of BA in the VRA (Wells and Deming, 2006), which can result in increases of BP and thus potentially increase VP (Helton et al., 2005; Weinbauer et al., 2009; Winget et al., 2005). However, Steward et al. (1996) found BS as high as 270 for areas of high productivity in 
Table 5. Comparison of viral abundance (VA) and production (VP), virus-mediated bacterial mortality (VMM) and \% loss of bacterial production $(\% \mathrm{BP})$ and standing stock per day $\left(\% \mathrm{SS} \mathrm{d}^{-1}\right)$ with literature data from other polar/subpolar environments.

\begin{tabular}{|c|c|c|c|c|c|c|c|c|}
\hline Location & Depth (m) & Method & VA $\left(10^{9} \mathrm{~L}^{-1}\right)$ & $\operatorname{VP}\left(10^{9} \mathrm{~L}^{-1} \mathrm{~d}^{-1}\right)$ & $\operatorname{VMM}\left(10^{8} \mathrm{~L}^{-1} \mathrm{~d}^{-1}\right)$ & $\% \mathrm{BP}$ & $\% \mathrm{SSd}^{-1}$ & Source \\
\hline SO : Fe-fertilized & $0-150$ & VRA & $3.4-14.2(9.9 \pm 3.6)$ & $9.9-117.9(59.0 \pm 47.1)$ & $0.8-10.3(5.4 \pm 4.1)$ & 8-202 (72) & 104 & Present study \\
\hline SO : HNLC & $0-200$ & VRA & $3.1-7.4(4.7 \pm 1.4)$ & $6.0-25.6(14.5 \pm 7.4)$ & $0.4-2.1(1.1 \pm 0.6)$ & $6-58(27)$ & 44 & Present study \\
\hline Antarctic & $0-100$ & VDR & $1-74(13 \pm 10.4)$ & & & $>100$ & & Guixa-Boixereu et al. (2002) \\
\hline SO-subantarctic & 10 & VRA & $6.1-26$ & $17.5-216.3$ & $3.6-43.3$ & $43-63$ & $40-130$ & Evans et al. (2009) \\
\hline SO & $5-200$ & VRA & $0.5-7.6$ & $0.4-16$ & $0-8.7$ & & $0-72$ & Evans and Brussaard (2012) \\
\hline SO : Fe patch & $10-150$ & VRA & $2.3-7(4.3 \pm 5.5)$ & $0.9-3.6(1.9 \pm 0.5)$ & & $41-172(104)^{*}$ & & Weinbauer et al. (2009) \\
\hline SO : HNLC & $10-150$ & VRA & $1.4-2.5(2.1 \pm 2)$ & $0.3-0.8(0.6 \pm 0.1)$ & & $14-70(39)^{*}$ & & Weinbauer et al. (2009) \\
\hline Arctic & $0-10$ & TEM & $2.5-36$ & $0.2-4.6(2)$ & & $2-36(13)$ & & Steward et al. (1996) \\
\hline North waters & $0-200$ & TEM & $1.36-5.55(3.3 \pm 1.6)$ & $0.1-1.3$ & & & $6-28$ & Middelboe et al. (2002) \\
\hline Arctic & $0-230$ & VDA & $1.4-4.5(2.8 \pm 1.3)$ & $0.1-1.9$ & $0.28-0.72$ & & & Wells and Deming (2006) \\
\hline Subarctic Fe patch & $0-10$ & TEM/VRA & 40.5 & $30-200$ & $90 \pm 25$ & & 7.4 & Higgins et al. (2009) \\
\hline Subarctic outside & $0-10$ & TEM/VRA & 35.7 & $30-200$ & $25.8 \pm 6.1$ & & 7.2 & Higgins et al. (2009) \\
\hline Arctic & $0-100$ & VRA & $0.32-7.28$ & $0.1-4.2$ & & $2-24(9)$ & $2-30$ & Boras et al. (2010) \\
\hline Canadian Arctic Shelf & $2-56$ & VRA & $2.7-27$ & $0.03-7.7$ & $0.02-4.3$ & $31-156$ & $1.4-29$ & Payet and Suttle (2013) \\
\hline
\end{tabular}

SO: Southern Ocean; VDR: viral decay rates; TEM: frequency of visibly infected cells by transmission electron microscopy; VDA: Virus dilution approach;

VRA: virus reduction approach. ${ }^{*}$ Using BP in the VRA.

the Chukchi Sea, and studies from the North Sea have reported 100 phages produced per lysed bacterium (Bratbak et al., 1992).

\subsection{Viruses in HNLC waters versus a phytoplankton bloom induced by natural iron fertilization}

Viral distribution during the late stage of the phytoplankton bloom above the Kerguelen Plateau as well as its relation to the bacterial hosts (e.g. VBR) and phytoplankton biomass is extensively reported, discussed and compared to existing data from similar regions in Brussard et al. (2008b). During the late bloom stage, average viral abundance at the bloom stations was twice as high as in HNLC waters (Brussaard et al., 2008b), while during the early bloom viral abundance remained unaffected (Christaki et al., 2014). Data from mesoscale $\mathrm{Fe}$ fertilization experiments showed that viral abundance inside the fertilized patch was higher (Weinbauer et al., 2009) or not substantially different from outside (Higgins et al., 2009). The authors of the latter study explained the lack of differences between inside and outside the fertilized patch with the time-lag of the microbial response to the induced bloom, since viral abundance and production were only increasing at the end of their observations (day 12 after iron fertilization). This observation is in line with the increase in viral abundance and activity on a seasonal scale in the Kerguelen bloom (Christaki et al., 2014).

The present study observed a mature bloom and could thus track a period with a more pronounced microbial response. The 4-times-higher viral production at the naturally Fe-fertilized study sites compares well to the 3 -fold increase in phage production after an induced bloom through iron addition (Weinbauer et al., 2009). Interestingly, Christaki et al. (2014) reported higher VP rates already at the early bloom stages. Thus, there is a trend of higher viral production in the iron-fertilized bloom compared to the surrounding HNLC waters consistent with existing data on iron fertilization (Weinbauer et al., 2009). Complementary, within the bloom, HNFs did not seem to control enhanced bacterial production rates, while in HNLC waters HNFs consumed $95 \%$ of bacterial production (Christaki et al., 2008). These studies suggest that there is a switch towards viral lysis dominating in the bloom situations. More generally, this is in accordance with previous studies across environments which showed viral influence to be more important in more eutrophic waters (Weinbauer et al., 1993; Steward et al., 1996), particulary in the cold environments such as the Arctic (Steward et al., 1996) or the Southern Ocean, where Guixa-Boixereu et al. (2002) found that viruses were responsible for the entire bacterial mortality. The high virally induced mortality in the bloom could also be a reason for low biomass accumulation, despite the high BP. We calculated carbon release rates through viral lysis in two ways: first, based on VP, and, second, based on VMM related to FIC by a model of Binder (1999) (Table 6). Independent of the absolute values, which were 1 order of magnitude higher in the former than in the latter way (Table 6), $\mathrm{C}$ release through viral lysis was 5-8 times higher in the Fe-fertilized than in the surrounding HNLC waters.

The percentages of lysogens (i.e. bacteria containing temperate viruses) were more variable in the fertilized (0-31\%) than in the HNLC waters $(0-4 \%)$ but not significantly different between environments. Consistent with our study, Weinbauer et al. (2009) did not find differences inside and outside the iron-enriched patch during a fertilization experiment in the Southern Ocean. The proportion of the lysogenized bacterial population can vary extensively, for example, from 1.5 to $11.4 \%$ in the Gulf of Mexico (Weinbauer and Suttle, 1996), from 4 to $38 \%$ in the Canadian Arctic Shelf (Payet and Suttle, 2013) and from 0 to $100 \%$ in Tampa Bay, Florida (Williamson et al., 2002). According to conceptual models, lysogeny should occur preferentially in environments where the contact rate between infective phages and hosts is too low to sustain the lytic lifestyle (Paul et al., 2002). Empirically, this has been proven by Weinbauer et al. (2003), who studied the frequency of lysogenic cells in contrasting 
Table 6. $\mathrm{C}$ and Fe release rates $\left(\mathrm{L}^{-1} \mathrm{~d}^{-1}\right)$ through viral lysis calculated from VP (12.4 $\mathrm{fg} \mathrm{C}$ cell $^{-1}$, Fukuda et al., 1998) and from FIC following the model by Binder (1999) using bacterial iron quota of $7.5 \mu \mathrm{Mol} \mathrm{Fe} \mathrm{mol} \mathrm{C}{ }^{-1}$ (Tortell et al., 1996). Averages are given in parenthesis.

\begin{tabular}{lllll}
\hline & \multicolumn{2}{c}{ Release based on VP } & \multicolumn{2}{c}{ Release based on FIC } \\
\hline & pmol Fe L & \\
& & $\mu m o l \mathrm{~d}^{-1}$ & $\mathrm{pmol} \mathrm{Fe} \mathrm{L}^{-1} \mathrm{~d}^{-1}$ & $\mu \mathrm{mol} \mathrm{CL}^{-1} \mathrm{~d}^{-1}$ \\
\hline Fertilized stations & $0.60-7.97(4.18 \pm 3.15)$ & $0.08-1.06(0.56 \pm 0.42)$ & $0.03-1.58(0.42 \pm 0.49)$ & $0.003-0.21(0.06 \pm 0.07)$ \\
HNLC stations & $0.28-1.60(0.86 \pm 0.43)$ & $0.04-0.21(0.11 \pm 0.06)$ & $0.004-0.12(0.05 \pm 0.05)$ & $0.001-0.02(0.01 \pm 0.01)$ \\
Ratio & $\mathbf{4 . 9}^{*}$ & $\mathbf{4 . 9}^{*}$ & $\mathbf{7 . 9}^{*}$ & $\mathbf{7 . 9}^{*}$ \\
\hline
\end{tabular}

* Values are significantly higher in the Fe-fertilized than in the HNLC stations (Kruskal-Wallis, $P<0.05$ ).

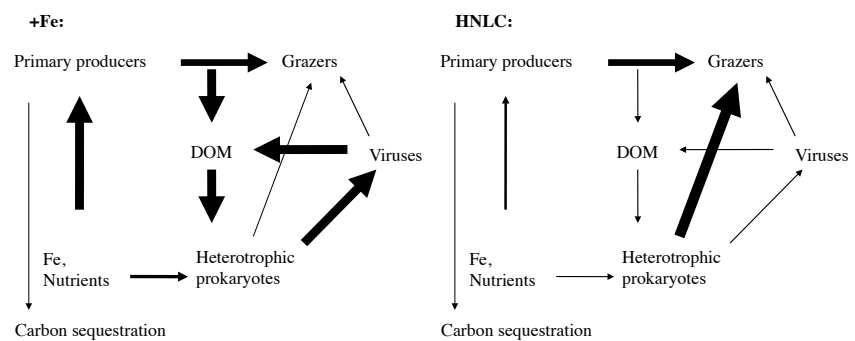

Figure 4. Simple sketch of the carbon and nutrient flow through the microbial food web in the Fe-fertilized (left) and HNLC waters (right). Arrow thickness represents the relative importance of factors controlling the size of each pool of the microbial food web.

marineenvironments and found the highest incidence of lysogens in deep waters where the host abundance is typically low, and by Payet and Suttle (2013) during a seasonal cycle study in the Arctic where lysogenic infection prevailed in periods of low system productivity. Apparently, this was not the case in the present study as the fraction of lysogenic cells was not different between trophic situations although bacterial and virus abundances and contact rates were significantly lower at the HNLC than at bloom stations (Table 2). It was suggested that enhanced growth causes temperate viruses to enter the lytic cycle (Wilson and Mann, 1997). Both filtration and incubation could have stimulated bacterial production in the virus reduction approach (Weinbauer et al., 2009) and consequently induced prophages in the mitomycin $\mathrm{C}$ treatment controls. Additionally, it has to be stressed that mitomycin $\mathrm{C}$ used as an inducing agent of lysogens in the natural bacterial communities may not induce all prophages and be toxic to some bacteria (Paul, 2008; Paul and Weinbauer, 2010). Thus, the apparent low incidence of lysogenic infection, particularly in HNLC waters, might be an artefact. However, it could also be that the study period was not long enough to induce potential changes of lysogenic infection. In addition, our study provides no evidence that lysogens were induced by relieving iron addition.

\subsection{Role of viruses for sustaining phytoplankton productivity by Fe supply}

Bacteria store about $50 \%$ of the biogenic iron in HNLC areas (Tortell et al., 1996) and the mode of bacterial mortality will affect the way of $\mathrm{Fe}$ regeneration and bioavailability (Kirchman, 1996; Mioni et al., 2005; Strzepek et al., 2005). While viral lysis liberates organically complexed iron, which may be assimilated rapidly, grazing mainly sets free inorganic $\mathrm{Fe}$ (Gobler et al., 1997; Poorvin et al., 2004). Assimilation studies with a model heterotrophic bacterium demonstrated that $\mathrm{Fe}$ in the virus-mediated cell lysates was more bioavailable than the siderophores produced by the same cells, supporting the importance of virus-mediated Fe regeneration in marine surface waters (Poorvin et al., 2011). We calculated Fe release rates in two ways: first, based on VP, and, second, based on VMM related to FIC by a model of Binder (1999). The former resulted in average iron regeneration rates due to viral lysis of bacteria of 4.18 and $0.86 \mathrm{pMol} \mathrm{Fe} \mathrm{d}^{-1}$ in fertilized and HNLC waters, respectively, while the latter resulted in more realistic values ranging from 0.03 to $1.58 \mathrm{pM} \mathrm{d}^{-1}$ (average: $0.42 \pm 0.49 \mathrm{pM} \mathrm{d}^{-1}$ ) in iron-fertilized waters and from 0.004 to $0.12 \mathrm{pM} \mathrm{d}^{-1}$ (average: $0.05 \pm 0.05 \mathrm{pM} \mathrm{d}^{-1}$ ) in HNLC waters (Table 6). These values are similar to those found in the Southern Ocean (Evans and Brussaard, 2012) and an iron-induced bloom (ibid., Weinbauer et al., 2009) but low compared to other studies. Poorvin et al. (2004) reported Fe regeneration rates of $19.2-75.5 \mathrm{pM} \mathrm{d}^{-1}$ in HNLC waters off Peru, and Strzepek et al. (2005) found a high range over 2 orders of magnitude of $0.4-28 \mathrm{pM} \mathrm{d}^{-1}$ in HNLC waters southeast of New Zealand. Fe regeneration rates are calculated from virally induced bacterial loss, which is inversely related to burst size. When taking into account that the calculated burst size in the present study was 5 times higher than the assumed BS in the study of Poorvin et al. (2004), the values in the present study compare well to data on $\mathrm{Fe}$ regeneration through viral activity from artificial fertilization experiments and other environments.

Significantly more iron was released by viral lysis within the naturally Fe-fertilized bloom than at the HNLC stations $(P<0.05$, Kruskal-Wallis, Table 6$)$. The concentration of dissolved iron in the surface mixed layer on and off 
the Kerguelen Plateau were typical for the open Southern Ocean and averaged $90 \pm 34 \mathrm{pM}$ (Blain et al., 2007), and the estimated biogenic iron pool at the main bloom station equaled $80 \pm 9 \mathrm{pM}$ (Sarthou et al., 2008). Taking into account the total $\mathrm{Fe}$ demand of the producers within the bloom of $6.04 \pm 0.62 \mathrm{pM} \mathrm{d}^{-1}$ (Sarthou et al., 2008), the remobilization of iron through viral lysis above the Kerguelen Plateau following the model by Binder (1999) accounts for up to $26 \%$ of the demand of the producers, and this appears to be a non-negligible iron source for sustaining plankton productivity.

\subsection{Implications for carbon cycling and sequestration}

Bacterial biomass and production were increased respectively from 287 to $797 \mathrm{mg} \mathrm{Cm}^{-2}$ and from 23.5 to $304 \mathrm{mg} \mathrm{C} \mathrm{m}^{-2} \mathrm{~d}^{-1}$ between the HNLC (C11) and the ironfertilized (A3) areas (Christaki et al., 2008). Bacterial abundance and production are often correlated with viral abundance and production. Thus, elevated bacterial activity in the (natural or induced) bloom could explain the enhanced viral abundance and production found in previous in situ $\mathrm{Fe}$ enrichment studies (Arrieta et al., 2000; Higgins et al., 2009; Weinbauer et al., 2009).

The finding of higher viral lysis rates of bacteria in the sites of natural Fe fertilization, where HNF grazing could only explain a small fraction of bacterial mortality (Christaki et al., 2008), has important implications for the carbon cycling. Due to enhanced viral lysis, less carbon will be transferred to larger members of the food web but becomes again part of the DOM pool (Middelboe et al., 1996). This viral shunt should result in elevated bacterial production and respiration; thus more $\mathrm{CO}_{2}$ would be produced and less carbon sequestrated. Experimental studies indicate that most of the lysis products belong to the labile fraction of DOM and are consequently rapidly degraded (Weinbauer et al., 2011). By the transformation of bacterial biomass into DOM, viruses have the effect of retaining carbon and nutrients in the photic zone (Suttle, 2007). Thus, viral lysis of bacteria could shortcircuit the biological pump (Brussaard et al., 2008a).

However, there are other possible scenarios. For example, microbial activity converts part of the organic matter into recalcitrant DOM (RDOM) that is resistant to microbial utilization and can persist in the interior of oceans for up to thousands of years. The detailed role of viral lysis in this new concept of the microbial carbon pump (MCP) (Jiao et al., 2010) is still poorly known. However, a compilation of data suggests that viral lysis increases the DOM pool and the ratio of recalcitrant vs. labile organic matter (Weinbauer et al., 2011). Thus, enhanced viral lysis of bacteria due to $\mathrm{Fe}$ fertilization could result in an enhanced carbon sequestration not related to the biological pump.

Rates of bacterial production $\left(\left[{ }^{3} \mathrm{H}\right]\right.$ leucine incorporation) and respiration $(<0.8 \mu \mathrm{m}$ size-fraction) were 5-6 times higher in the bloom at station A3 than those in surrounding
HNLC waters, indicating that heterotrophic bacteria within the bloom processed a significant portion of primary production, with most of it being rapidly respired (Obernosterer et al., 2008), fuelling the $\mathrm{CO}_{2}$ pool. This scenario is coherent with the finding of small particulate organic carbon export fluxes to depth necessary for long-term sequestration (de Baar et al., 2005; Street and Paytan, 2005), despite the role of iron in regulating primary productivity. However, most in situ mesoscale iron enrichment experiments so far performed in the HNLC regions did not last long enough to follow the termination of the bloom (Buesseler and Boyd, 2003; Smetacek et al., 2012). In the present study, we sampled a bloom in its late successional stage and could thereby track the fate of fixed carbon by an iron-fertilized phytoplankton bloom. Figure 4 shows a simple sketch to highlight the importance of each compartment of the microbial food web in the transfer of organic material in an Fe-fertilized bloom compared to HNLC waters. Sequestration of material in viruses, bacteria and dissolved matter may lead to stronger retention of nutrients in the euphotic zone in systems with high viral lysis rates of bacteria, because more material remains in these small, non-sinking forms. This could be of major importance for large-scale iron fertilization of ocean regions as a means of enhancing the ability of the ocean to store anthropogenic $\mathrm{CO}_{2}$ and mitigate 21 st-century climate change.

\section{Conclusions}

Enhanced bacterial production following the iron-fertilized phytoplankton bloom induced a switch from grazing to viral lysis as major mechanisms causing bacterial mortality. This could change the carbon flow through the microbial food web. We suggest that enhanced viral lysis of bacteria short-circuits the biological pump but potentially primes the microbial carbon pump.

Acknowledgements. We thank the chief scientists (S. Blain and B. Quéguiner) for the possibility to participate in this cruise, the captain and crew of R/V Marion Dufresne for their efficient assistance during work at sea and the colleagues for help onboard. The financial support was provided by the European Union in the framework of the BASICS project (EVK3-CT-2002-00078), by the French research program of the INSU-CNRS PROOF, the French Polar Institute (IPEV) and a Spanish grant from the Ministry of Education (SB2010-0079) to A. Malits.

Edited by: B. Quéguiner 


\section{References}

Arrieta, J. M., Weinbauer, M. G., and Herndl, G. J.: Interspecific variability in sensitivity to uv radiation and subsequent recovery in selected isolates of marine bacteria, Appl. Environ. Microb., 66, 1468-1473, 2000.

Bergh, O., Børsheim, K. Y., Bratbak, G., and Heldal, M.: High abundance of viruses found in aquatic environments, Nature, 340, 467-468, 1989.

Biller, S. J., Schubotz, F., Roggensack, S. E., Thompson, A. W., Summons, R. E., and Chisholm, S. W.: Bacterial vesicles in marine ecosystems, Science, 343, 183-186, doi:10.1126/science.1243457, 2014.

Binder, B.: Reconsidering the relationship between virally induced bacterial mortality and frequency of infected cells, Aquat. Microb. Ecol., 18, 207-215, 1999.

Bird, D. F., Maranger, R., and Karl, D.: Palmer lter: Aquatic virus abundances near the antarctic peninsula, Antarct. J. US., 28, 234$235,1993$.

Blain, S., Queguiner, B., Armand, L., Belviso, S., Bombled, B., Bopp, L., Bowie, A., Brunet, C., Brussaard, C., Carlotti, F., Christaki, U., Corbiere, A., Durand, I., Ebersbach, F., Fuda, J. L., Garcia, N., Gerringa, L., Griffiths, B., Guigue, C., Guillerm, C., Jacquet, S., Jeandel, C., Laan, P., Lefevre, D., Lo Monaco, C., Malits, A., Mosseri, J., Obernosterer, I., Park, Y. H., Picheral, M., Pondaven, P., Remenyi, T., Sandroni, V., Sarthou, G., Savoye, N., Scouarnec, L., Souhaut, M., Thuiller, D., Timmermans, K., Trull, T., Uitz, J., van Beek, P., Veldhuis, M., Vincent, D., Viollier, E., Vong, L., and Wagener, T.: Effect of natural iron fertilization on carbon sequestration in the southern ocean, Nature, 446, 10701074, 2007.

Blain, S., Queguiner, B., and Trull, T.: The natural iron fertilization experiment keops (kerguelen ocean and plateau compared study): An overview, Deep-Sea Res. Pt.-II, 55, 559-565, 2008.

Bonilla-Findji, O., Malits, A., Lefevre, D., Rochelle-Newall, E., Lemee, R., Weinbauer, M. G., and Gattuso, J.-P.: Viral effects on bacterial respiration, production and growth efficiency: Consistent trends in the southern ocean and the mediterranean sea, Deep-Sea Res. Pt.-II, 55, 790-800, 2008.

Boras, J. A., Sala, M. M., Vazquez-Dominguez, E., Weinbauer, M. G., and Vaque, D.: Annual changes of bacterial mortality due to viruses and protists in an oligotrophic coastal environment (nw mediterranean), Environ. Microbiol., 11, 1181-1193, doi:10.1111/j.1462-2920.2008.01849.x, 2009.

Boras, J., Sala, M., Arrieta, J., Sà, E., Felipe, J., Agustí, S., Duarte, C., and Vaqué, D.: Effect of ice melting on bacterial carbon fluxes channelled by viruses and protists in the arctic ocean, Polar Biol., 33, 1695-1707, doi:10.1007/s00300-010-0798-8, 2010.

Bratbak, G., Heldal, M., Thingstad, T. F., Riemann, B., and Haslund, O. H.: Incorporation of viruses into the budget of microbial c-transfer, A first approach, Mar. Ecol. Prog. Ser., 83, 273-280, 1992.

Brussaard, C. P. D.: Optimization of procedures for counting viruses by flow cytometry, Appl. Environ. Microbiol., 70, 1506-1513, 2004.

Brussaard, C. P. D., Wilhelm, S. W., Thingstad, F., Weinbauer, M. G., Bratbak, G., Heldal, M., Kimmance, S. A., Middelboe, M., Nagasaki, K., Paul, J. H., Schroeder, D. C., Suttle, C. A., Vaque, D., and Wommack, K. E.: Global-scale processes with a nanoscale drive: The role of marine viruses, Isme J., 2, 575-578, doi:10.1038/ismej.2008.31, 2008a.

Brussaard, C. P. D., Timmermans, K. R., Uitz, J., and Veldhuis, M. J. W.: Virioplankton dynamics and virally induced phytoplankton lysis versus microzooplankton grazing southeast of the kerguelen (southern ocean), Deep-Sea Res. Pt.-II, 55, 752-765, 2008 b.

Buesseler, K. O. and Boyd, P. W.: Climate change, Will ocean fertilization work?, Science, 300, 67-68, 2003.

Christaki, U., Obernosterer, I., Van Wambeke, F., Veldhuis, M., Garcia, N., and Catala, P.: Microbial food web structure in a naturally iron fertilized area in the southern ocean (kerguelen plateau), Deep-Sea Res. Pt.-II, 55, 706-719, 2008.

Christaki, U., Lefèvre, D., Georges, C., Colombet, J., Catala, P., Courties, C., Sime-Ngando, T., Blain, S., and Obernosterer, I.: Microbial food web dynamics during spring phytoplankton blooms in the naturally iron-fertilized Kerguelen area (Southern Ocean), Biogeosciences, 11, 6739-6753, doi:10.5194/bg-116739-2014, 2014.

Daughney, C. J., Chatellier, X., Chan, A., Kenward, P., Fortin, D., Suttle, C. A., and Fowle, D. A.: Adsorption and precipitation of iron from seawater on a marine bacteriophage (pwh3a-p1), Mar. Chem., 91, 101-115, 2004.

de Baar, H. J. W., Boyd, P. W., Coale, K. H., Landry, M. R., Tsuda, A., ASSMY, P., Bakker, D. C. E., Bozec, Y., Barber, R. T., Brzezinski, M. A., Buesseler, K. O., Boye, M., Croot, P L., Gervais, F., Gorbunov, M. Y., Harrison, P. J., Hiscock, M. R., Laan, P., Lancelot, C., Law, C. S., Levasseur, M., Marchetti, A., Millero, F. J., Nishioka, J., Nojiri, Y., van Oijen, T., Riebesell, U., Rijkenberg, M. J. A., Saito, H., Takeda, S., Timmermans, K. L., Veldhuis, M. J. W., Waite, A. M., and Wong, C. S.: Synthesis of iron fertilization experiments: From the iron age in the age of enlightenment, J. Geophys. Res., 110, C09S16, doi:10.1029/2004JC002601, 2005.

Evans, C. and Brussaard, C. P. D.: Regional variation in lytic and lysogenic viral infection in the southern ocean and its contribution to biogeochemical cycling, Appl. Environ. Microbiol., 78, 6741-6748, doi:10.1128/aem.01388-12, 2012.

Evans, C., Pearce, I., and Brussaard, C. P. D.: Viral-mediated lysis of microbes and carbon release in the sub-antarctic and polar frontal zones of the australian southern ocean, Environ. Microbiol., 11, 2924-2934, 2009.

Fuhrman, J. A.: Marine viruses and their biogeochemical and ecological effects, Nature, 399, 541-548, 1999.

Fuhrman, J. A. and Noble, R. T.: Viruses and protists cause similar bacterial mortality in coastal seawater, Limnol. Oceanogr., 40, 1236-1242, 1995.

Fukuda, R., Ogawa, H., Nagata, T., and Koike, I. I.: Direct determination of carbon and nitrogen contents of natural bacterial assemblages in marine environments, Appl. Environ. Microb., 64, 3352-3358, 1998.

Gasol, J. M., Zweifel, U. L., Peters, F., Fuhrman, J. A., and Hagstrom, A.: Significance of size and nucleic acid content heterogeneity as measured by flow cytometry in natural planktonic bacteria, Appl. Environ. Microb., 65, 4475-4483, 1999.

Gobler, C. J., Hutchins, D. A., Fisher, N. S., Cosper, E. M., and Sanudo-Wilhelmy, S. A.: Release and bioavailability of C, N, P, $\mathrm{Se}$, and $\mathrm{Fe}$ following viral lysis of a marine chrysophyte, Limnol. Oceanogr., 42, 1492-1504, 1997. 
Guixa-Boixereu, N., Vaqué , D., Gasol, J. M., Sánchez-Cámara, J., and Pedrós-Alió, C.: Viral distribution and activity in antarctic waters, Deep-Sea Res., 49, 827-845, 2002.

Helton, R. R., Cottrell, M. T., Kirchman, D. L., and Wommack, K. E.: Evaluation of incubation-based methods for estimating virioplankton production in estuaries, Aquat. Microb. Ecol., 41, 209219, 2005

Higgins, J. L., Kudo, I., Nishioka, J., Tsuda, A., and Wilhelm, S. W.: The response of the virus community to the seeds ii mesoscale iron fertilization, Deep-Sea Res. Pt.-II, 56, 2788-2795, 2009.

Jiao, N., Herndl, G. J., Hansell, D. A., Benner, R., Kattner, G., Wilhelm, S. W., Kirchman, D. L., Weinbauer, M., G., Luo, T., Chen, F., and Azam, F.: Microbial production of recalcitrant dissolved organic matter: Long-term carbon storage in the global ocean, Nat. Rev. Microbiol., 8, 593-599, 2010.

Kirchman, D. L.: Leucine incorporation as a measure of biomass production by heterotrophic bacteria, in: Handbook of methods in aquatic microbial ecology, edited by: Kemp, P. F., Sherr, B. F., Sherr, E. B., and Cole, J. J., Lewis Publishers, Boca Raton, FL, 509-512, 1993.

Kirchman, D. L.: Microbial ferrous wheel, Nature, 383, 303-304, 1996.

Manganelli, M., Malfatti, F., Samo, T. J., Mitchell, B. G., Wang, H., and Azam, F.: Major role of microbes in carbon fluxes during austral winter in the southern drake passage, PLoS ONE, 4, e6941, doi:10.1371/journal.pone.0006941, 2009.

Marchant, H., Davidson, A., Wright, S., and Glazebrook, J.: The distribution and abundance of viruses in the southern ocean during spring, Antarct. Sci., 12, 414-417, 2000.

Martin, J. H.: Glacial interglacial $\mathrm{CO}_{2}$ change: The iron hypothesis, Paleoceanography, 5, 1-13, 1990.

Martin, J. H. and Fitzwater, S. E.: Iron deficiency limits phytoplankton growth in the north-east pacific subarctic, Nature, 331, 341343,1988

Middelboe, M. and Lyck, P. G.: Regeneration of dissolved organic matter by viral lysis in marine microbial communities, Aquat. Microb. Ecol., 27, 187-194, 2002.

Middelboe, M., Jorgensen, N., and Kroer, N.: Effects of viruses on nutrient turnover and growth efficiency of noninfected marine bacterioplankton, Appl. Environ. Microbiol., 62, 1991-1997, 1996.

Mioni, C. E., Poorvin, L., and Wilhelm, S. W.: Virus and siderophore-mediated transfer of available fe between heterotrophic bacteria: Characterization using an fe-specific bioreporter, Aquat. Microb. Ecol., 41, 233-245, 2005.

Mosseri, J., Quéguiner, B., Armand, L., and Cornet-Barthaux, V.: Impact of iron on silicon utilization by diatoms in the southern ocean: A case study of $\mathrm{si} / \mathrm{n}$ cycle decoupling in a naturally ironenriched area, Deep-Sea Res. Pt.-II, 55, 801-819, 2008.

Murray, A. G. and Jackson, A. G.: Viral dynamics: A model of the effects of size, shape, motion and abundance if single-celled planktonic organisms and other particles, Mar. Ecol. Prog. Ser., 89, 103-116, 1992.

Obernosterer, I., Christaki, U., Lefevre, D., Catala, P., Van Wambeke, F., and Lebaron, P.: Rapid bacterial mineralization of organic carbon produced during a phytoplankton bloom induced by natural iron fertilization in the southern ocean, Deep-Sea Res. Pt.-II, 55, 777-789, 2008.
Park, Y.-H., Roquet, F., Durand, I., and Fuda, J.-L.: Large-scale circulation over and around the northern kerguelen plateau, DeepSea Res. Pt.-II, 55, 566-581, doi:10.1016/j.dsr2.2007.12.030, 2008.

Paul, J. H.: Prophages in marine bacteria: Dangerous molecular time bombs or the key to survival in the seas?, Isme J., 2, 579589, 2008.

Paul, J. H. and Weinbauer, M. G.: Detection of lysogeny in marine environments, in: Manual of Aquatic Virus Ecology, ASLO, edited by: Suttle, C. A., Wilhelm, S. W., and Weinbauer, M. G., 30-33, 2010.

Paul, J. H., Sullivan, M. B., Segall, A. M., and Rohwer, F.: Marine phage genomics, Comp. Biochem. Phys. B., 133, 463-476, 2002.

Payet, J. P. and Suttle, C. A.: Physical and biological correlates of virus dynamics in the southern beaufort sea and amundsen gulf, Sea ice and life in a river-influenced arctic shelf ecosystem, J. Mar. Syst., 74, 933-945, 2008.

Payet, J. P. and Suttle, C. A.: To kill or not to kill: The balance between lytic and lysogenic viral infection is driven by trophic status, Limnol. Oceanogr., 58, 465-474, 2013.

Poorvin, L., Rinta-Kanto, J. M., Hutchins, D. A., and Wilhelm, S. W.: Viral release of iron and its bioavailability to marine plankton, Limnol. Oceanogr., 49, 1734-1741, 2004.

Poorvin, L., Sander, S. G., Velasquez, I., Ibisanmi, E., LeCleir, G. R., and Wilhelm, S. W.: A comparison of fe bioavailability and binding of a catecholate siderophore with virus-mediated lysates from the marine bacterium vibrio alginolyticus pwh3a, J. Exp. Mar. Biol. Ecol., 399, 43-47, 2011.

Proctor, L. M. and Fuhrman, J. A.: Viral mortality of marine bacteria and cyanobacteria, Nature, 343, 60-62, 1990.

Rue, E. L. and Bruland, K. W.: The role of organic complexation on ambient iron chemistry in the equatorial pacific ocean and the response of a mesoscale iron addition experiment, Limnol. Oceanogr., 43, 901-910, 1997.

Sarthou, G., Vincent, D., Christaki, U., Obernosterer, I., Timmermans, K. R., and Brussaard, C. P. D.: The fate of biogenic iron during a phytoplankton bloom induced by natural fertilization: Impact of copepod grazing, Deep-Sea Res. Pt.-II, 55, 734-751, 2008.

Smetacek, V., Klaas, C., Strass, V. H., Assmy, P., Montresor, M., Cisewski, B., Savoye, N., Webb, A., d/'Ovidio, F., Arrieta, J. M., Bathmann, U., Bellerby, R., Berg, G. M., Croot, P., Gonzalez, S., Henjes, J., Herndl, G. J., Hoffmann, L. J., Leach, H., Losch, M., Mills, M. M., Neill, C., Peeken, I., Rottgers, R., Sachs, O., Sauter, E., Schmidt, M. M., Schwarz, J., Terbruggen, A., and Wolf-Gladrow, D.: Deep carbon export from a southern ocean iron-fertilized diatom bloom, Nature, 487, 313-319, 2012.

Smith, D. C. and Azam, F.: A simple, economical method for measuring bacterial protein synthesis rates in seawater using ${ }^{3} \mathrm{~h}$ leucine, Mar. Microb. Food Webs, 6, 107-114, 1992.

Smith, D. C., Steward, G. F., and Azam, F.: Virus and bacteria abundances in the drake passage during january and august 1991, Antarct. J. US., 27, 125-127, 1992.

Steward, G. F., Smith, D. C., and Azam, F.: Abundance and production of bacteria and viruses in the bering and chukchi seas, Mar. Ecol. Prog. Ser., 131, 287-300, 1996.

Street, J. H. and Paytan, A.: Iron, phytoplankton growth, and the carbon cycle, Met. Ions. Biol. Syst., 43, 153-193, 2005. 
Strzepek, R. F., Maldonado, M. T., Higgins, J. L., Hall, J., Safi, K., Wilhelm, S. W., and Boyd, P.: Spinning the "ferrous wheel": The importance of the microbial community in an iron budget during the fecycle experiment, Global Biogeochem. Cy., 19, GB4S26, doi:10.1029/2005GB002490, 2005.

Suttle, C. A.: Marine viruses-major players in the global ecosystem, Nat. Rev. Microbiol., 5, 801-812, 2007.

Suttle, C. A., Chan, A. M., and Cottrell, M. T.: Infection of phytoplankton by viruses and reduction of primary productivity, Nature, 347, 467-469, 1990.

Tortell, P. D., Maldonado, M. T., and Price, N. M.: The role of heterotrophic bacteria in iron-limited ocean ecosystems, Nature, 383, 330-332, 1996.

Uitz, J., Claustre, H., Griffiths, F. B., Ras, J., Garcia, N., and Sandroni, V.: A phytoplankton class-specific primary production model applied to the Kerguelen Islands region (Southern Ocean), Deep Sea Res. Pt.-I, 56, 541-560, 2009.

Van Heukelem, L. and Thomas, C. S.: Computer-assisted highperformance liquid chromatography method development with applications to the isolation and analysis of phytoplankton pigments, J. Chromatogr. A, 910, 31-49, 2001.

Weinbauer, M. G. and Suttle, C. A.: Potential significance of lysogeny to bacteriophage production and bacterial mortality in coastal waters of the gulf of mexico, Appl. Environ. Microbiol., 62, 4374-4380, 1996.

Weinbauer, M. G., Fuks, D., and Peduzzi, P.: Distribution of viruses and dissolved DNA along a coastal trophic gradient in the northern adriatic sea, Appl. Environ. Microbiol., 59, 4074-4082, 1993.

Weinbauer, M., Winter, C., and Höfle, M.: Reconsidering transmission electron microscopy based estimates of viral infection of bacterioplankton using conversion factors derived from natural communities, Aquat. Microb. Ecol., 27, 103-110, 2002.

Weinbauer, M. G., Brettar, I., and Höfle, M. G.: Lysogeny and virus-induced mortality of bacterioplankton in surface, deep, and anoxic marine waters, Limnol. Oceanogr., 48, 1457-1465, 2003.
Weinbauer, M. G., Arrieta, J. M., Griebler, C., and Herndl, G. J.: Enhanced viral production and infection of bacterioplankton during an iron induced phytoplankton bloom in the southern ocean, Limnol. Oceanogr., 54, 774-784, 2009.

Weinbauer, M. G., Rowe, J. M., and Wilhelm, S. W.: Determining rates of virus production in aquatic systems by the virus reduction approach, in: Manual of Aquatic Virus Ecology, ASLO, edited by: Suttle, C. A., Wilhelm, S. W., and Weinbauer, M. G., $1-8,2010$.

Weinbauer, G., Chen, F., and Wilhelm, A. W.: Virus-mediated redistribution and partitioning of carbon in the global oceans, in: Microbial carbon pump, edited by: Jiao, N., Azam, F., and Sanders, S., Science/AAAS, Washington, DC, 54-56, 2011.

Wells, L. E. and Deming, J. W.: Significance of bacterivory and viral lysis in bottom waters of franklin bay, canadian arctic, during winter, Aquat. Microb. Ecol., 43, 209-221, 2006.

Wilhelm, S. W. and Suttle, C. A.: Virus and nutrient cycles in the sea, BioScience, 49, 781-787, 1999.

Wilhelm, S. W., Weinbauer, M. G., Suttle, C. A., and Jeffrey, W. H.: The role of sunlight in the removal and repair of viruses in the sea, Limnol. Oceanogr., 43, 586-592, 1998.

Wilhelm, S., Brigden, S., and Suttle, C.: A dilution technique for the direct measurement of viral production: A comparison in stratified and tidally mixed coastal waters, Microb. Ecol., 43, 168173, 2002.

Williamson, S. J., Houchin, L. A., McDaniel, L., and Paul, J. H.: Seasonal variation in lysogeny as depicted by prophage induction in tampa bay, florida, Appl. Environ. Microbiol., 68, 4307-4314, 2002.

Wilson, W. H. and Mann, N. H.: Lysogenic and lytic viral production in marine microbial communities, Aquat. Microb. Ecol., 13 , 95-100, 1997.

Winget, D. M., Williamson, K. E., Helton, R. R., and Wommack, K. E.: Tangential flow diafiltration: An improved technique for estimation of virioplankton production, Aquat. Microb. Ecol., 41, 221-232, 2005. 